\title{
GUERRA JUSTA, HERMENÊUTICA POLITICA E PLURALISMO RELIGIOSO EM JOHN RAWLS E CLAUDE GEFFRÉ
}

\author{
Just War, Political hermeneutics and Religious \\ PLURALISM IN JOHN RAWLS AND CLAUDE GEFFRÉ
}

\author{
Nythamar de Oliveira* \\ Tiago de Fraga Gomes**
}

\section{RESUMO}

Para John Rawls é primordialmente importante para o Direito dos Povos que a justiça seja assegurada pela estabilidade de sociedades liberais e decentes. Uma intervenção militar com fins humanitários ou autodefesa seria uma resposta legítima aos abusos perpetrados pelos grupos ou Estados "fora da lei", na medida em que fomentam a guerra e o terrorismo, o que poderia ser caracterizada como uma instância de "guerra justa". A hermenêutica política emerge no espaço de razão pública onde se propõe a conciliação e o acordo entre as doutrinas religiosas e as concepções abrangentes de bem comum, com seus conflitos e incompatibilidades. O liberalismo político busca acomodar tal pluralidade de doutrinas abrangentes razoáveis através do consenso sobreposto. Claude Geffré propõe uma teologia com orientação hermenêutica como uma nova postura política diante do pluralismo hodierno. O enigma da alteridade plural das concepções religiosas manifesta a riqueza espiritual da vivência humana do divino, porém, levanta importantes questionamentos para a convivência social. Rawls e Geffré convergem quanto ao problema hermenêutico da justificação normativa postulada num contexto pluralista de reconhecimento do outro e de tolerância em face às querelas irreconciliáveis.

Palavras-chave: Guerra justa. Teologia política. Pluralismo religioso. John Rawls. Claude Geffré.

* Professor dos PPGs em Filosofia e em Teologia da PUCRS. Doutor em Filosofia. Mestre em Teologia e em Filosofia. Licenciado em Teologia. Possui 6 pós-doutorados no exterior. Pesquisador CNPq.

** Doutorando em Teologia pela PUCRS. Mestre em Teologia. Bacharel em Teologia e em Filosofia.

\begin{tabular}{|l|l|l|l|l|l|}
\hline Teocomunicação & Porto Alegre & v. 46 & n. 1 & p. 59-86 & jan.-jun. 2016 \\
\hline
\end{tabular}




\begin{abstract}
For John Rawls, it is primarily important for the Law of Peoples that justice be served through the stability of liberal and decent societies. Military intervention for humanitarian or self-defense purposes was a legitimate response to abuses perpetrated by outlaw groups or States, as they fuel war and terrorism, in which case could be characterized as an instance of "just war". The political hermeneutics emerges in the public space because of the proposed conciliation and agreement between religious doctrines and comprehensive conceptions of the common good with their conflicts and incompatibilities. Political liberalism seeks to accommodate such a plurality of reasonable comprehensive doctrines through overlapping consensus. Claude Geffré proposes a theology with hermeneutical orientation as a new political stance in the face of today's pluralism. The enigma of the plural otherness of religious conceptions manifest the spiritual richness of the human experience of the divine, and yet it raises important questions for social cohesion. Rawls and Geffré converge on the hermeneutical problem of normative justification postulated in a pluralistic context of recognition of the other and tolerance in the face of irreconcilable quarrels.
\end{abstract}

Keywords: Just war. Political theology. Religious pluralism. John Rawls. Claude Geffré.

\title{
Introdução
}

Qualquer tentativa de empreender uma reconstrução normativa dos argumentos político-liberais em defesa da guerra justa deve inevitavelmente lidar com três níveis diferenciados de argumentação, a saber: (1) o problema ontológico-semântico, compreendendo questões epistêmicas de significado e de linguagem, visando uma definição do que é, afinal, uma guerra justa, levando em consideração não apenas as condições empíricas, geopolíticas e históricas concretas do fenômeno da guerra (portanto, de que sempre houve e ainda há guerras no mundo), mas também das mudanças conceituais e de contextos semânticos em torno da ideia de guerra justa; (2) o problema da antropologia filosófica e da historicidade (compreendendo diferentes versões de filosofia da história, teológicas, como a teodiceia, ou não, como versões metafísicas, hegelianas, marxistas e comunitaristas que se opõem a teorias jusnaturalistas, contratualistas e liberais) em torno de conceitos fundamentais tais como liberdade, igualdade, socialidade e progresso humano; (3) o problema hermenêutico de como interpretar, justificar 
e defender a guerra justa, sobretudo numa abordagem pluralista, intercultural e transcultural, pautada pelo reconhecimento do Outro, num viés hermenêutico de diálogo e tolerância, com ou sem pretensão explícita de validade universalista ${ }^{1}$.

Tentaremos esboçar esses três níveis, sobretudo o problema da correlação entre o que seria uma hermenêutica pluralista de coexistência pacífica em situações de ameaça bélica e instabilidade política, e o que pode ser tomado como reivindicação normativa de universalizabilidade (por exemplo, que as normas inerentes ao problema da guerra justa possam satisfazer uma concepção minimalista de direitos humanos). Seguindo as indeléveis contribuições do cosmopolitismo de Immanuel Kant, de seus críticos comunitaristas e de pensadores da civilização democrático-liberal contemporânea, escolhemos dois representantes da teologia política em sua confluência entre uma filosofia político-liberal da guerra justa e uma hermenêutica político-teológica do diálogo interreligioso e transcultural: John Rawls e Claude Geffré. Guardadas as suas diferenças, Rawls e Geffré convergem quanto ao problema hermenêutico da justificação normativa que se postula num contexto pluralista de reconhecimento do Outro e de tolerância em face dos conflitos entre doutrinas abrangentes (mais especificamente, religiões) irreconciliáveis e incompatíveis entre si.

Segundo o dominicano Claude Geffré, uma teologia com orientação hermenêutica designa o destino da razão teológica no contexto do pensável contemporâneo, pois diz respeito a uma nova postura diante do pluralismo religioso hodierno. Diante da atual polifonia religiosa entoada pela multiplicidade de religiões do mundo, o cristianismo é chamado a expressar e a redefinir a sua identidade singular. A disposição em retomar de modo criativo o sentido da fé em vista das novas experiências históricas traz uma vitalidade aos enunciados da fé2. Há um enigma presente na alteridade plural das concepções religiosas, cuja manifestação expressa a riqueza espiritual da vivência humana do divino. Diante desses apelos, Geffré enfatiza que a teologia hermenêutica não pode ser concebida sem uma prática, do contrário, cai no âmbito da pura ideologia. "A teologia hermenêutica não se reduz a uma interpretação puramente teórica do cristianismo, mas conduz a uma transformação

1 OLIVEIRA, N. Revisitando a crítica comunitarista ao liberalismo: Sandel, Rawls e teoria crítica. p. 393.

2 GOMES, T. F. Hermenêutica teológica e teologia da revelação em Claude Geffré, p. 49. 
efetiva do mundo e da história"3. Nesse sentido, a teologia precisa não só a produzir conteúdos significativos, mas deve conduzir a práticas significantes.

Para o episcopal (anglicano) John Rawls, em um distanciamento agnóstico-metodológico opera-se uma verdadeira mudança de paradigma quando saímos de um procedimentalismo puro ou abstrato (por exemplo, na concepção de justiça como equidade em sua obraprima de 1971, A Theory of Justice) em direção a uma hermenêutica concreta de pluralismo razoável, onde se coloca o problema da guerra justa entre povos e civilizações, sobretudo para as democracias liberais em suas relações diplomáticas com povos não-liberais.

\section{O liberalismo político de Rawls e a questão da guerra justa}

As contribuições de Rawls para reabilitar uma teoria liberal da guerra justa não são, decerto, tão conhecidas quanto a sua concepção procedimental dos princípios de justiça formulados a partir de uma posição original hipotética, mas as intuições rawlsianas aplicadas ao cenário internacional se mostraram uma alternativa a modelos conservadores que respondem ao desafio do realismo político (o estado hobbesiano permanente de ameaças de retorno a um estado de guerra) com propostas de realização do liberalismo pelo capitalismo globalizado assumindo uma tese de fim da história (Francis Fukuyama) ou como resposta de estratégia militar e geopolítica ao choque de civilizações (Samuel Huntington).

Desde os escritos de historiadores gregos como Tucídides e Heródoto sobre as Guerras do Peloponeso e as batalhas do mundo helênico, sobretudo contra os persas, até os escritos mais recentes de Michael Walzer e Eric Hobsbawm sobre a guerra justa e a era dos extremos no século passado, temos assistido a um infindável ciclo de conflitos bélicos que fazem da guerra a mais paradoxalmente humana de todas as características fundamentais do ser humano em sua "insociável

\footnotetext{
3 GOMES, T. F. A teologia hermenêutica de Claude Geffré e a sua relevância para a teologia da revelação, p. 38. Nessa mesma linha, afirma Ernildo Stein que "a hermenêutica está necessariamente referida à práxis." (STEIN, E. Aproximações sobre hermenêutica, p. 86). Toda teoria interpretativa deve ser pertinente a uma prática transformadora, tendo assim, uma relevância social e política.
} 
sociabilidade", segundo a lapidar fórmula kantiana ${ }^{4}$. Assim como foi e pode até hoje ser diversamente definido como Homo sapiens, homo faber, homo oeconomicus e homo religiosus, o ser humano é, com efeito, o homo bellicus por excelência, pois nenhum outro animal na história evolutiva conhecida de nosso planeta depende tanto do conflito belicoso para sobreviver, isto é, paradoxalmente, só o ser humano se caracteriza como um animal que vincula a sua sobrevivência à matança racionalizada de membros de sua própria espécie - pelos motivos mais diversos: econômicos, políticos, sociais, religiosos, morais ou até filosóficos. Esta definição seria, de resto, a de uma investigação interdisciplinar sobre a guerra em história, ciências sociais e filosofia ${ }^{5}$. Parafraseando Alexander Solzhenitsyn, podemos constatar que nada há de mais humano e inumano na humanidade do que o perpétuo conflito e cessação de hostilidades nos intermináveis processos de guerra e paz enquanto cessação de hostilidades ${ }^{6}$.

A importância da reflexão filosófica em torno do tema da guerra justa consiste precisamente em resgatar uma dimensão ética, normativa, para justificar por que devemos defender a paz e condenar a guerra, e por que, apesar de tal postura, terminamos por defender um uso legítimo da força e da violência pelo Estado e, em certas condições, de uma guerra justa na medida em que sirva para promover a $\mathrm{paz}^{7}$. Assim, podemos reexaminar em que sentido a proposta ético-normativa de inspiração contratualista, mais precisamente, kantiana, quando combinada com uma hermenêutica pluralista, ainda se mostra como uma das mais defensáveis para justificar como evitar a guerra e promover a paz entre os povos, sobretudo na medida em que viabiliza uma reformulação hermenêutica da inclusão do Outro pelo reconhecimento e diálogo intercultural.

$\mathrm{O}$ tema da guerra justa (justum bellum) foi abordado por diversos pensadores medievais e clássicos como S. Tomás de Aquino e Hugo Grotius, mas já o encontramos em várias passagens da Bíblia, daí a sua importância programática para uma teologia política. Trata-se de formular uma argumentação moral com o intuito de justificar a guerra,

4 WALZER, M. Just and unjust wars: a moral argument with historical illustrations; HOBSBAWM, E. A era dos extremos: o breve século XX: 1914-1991; HUNTINGTON, S. O choque de civilizações e a recomposição da ordem mundial.

5 STRACHAN, H. European armies and the conduct of war; STRACHAN, H. The first world war: to Arms; STRACHAN, H. Financing the war.

6 SOLZHENITSYN, A. Uma palavra de verdade.

7 NARDIN, T. (Org.). The ethics of war and peace. 
sobretudo numa situação de defesa do povo de Deus ou dentro do plano divino para a humanidade, onde os horrores e sofrimentos de uma dada situação bélica se justificam à luz de um bem maior ou da paz a serem conquistados num futuro imediato. A guerra seria, neste caso, concebida como uma espécie de "mal necessário" ou inevitável, num contexto histórico-semântico particular, mas na verdade seria justificada num contexto mais amplo pela própria soberania do Senhor da História (Adon Olam), que é também o Senhor dos Exércitos (Adon HaTzevaoth) - como argumentam os arautos da teodiceia (do grego, diké tou theou, "juízo divino") desde Agostinho e Leibniz (que cunhou o termo em sua obra de 1710, Essais de Théodicée sur la bonté de Dieu, la liberté de l'homme et l'origine du mal), em resposta ao problema do mal num universo criado, sustentado e governado por um Deus benévolo, onisciente e onipotente. Assim, as regras que governam a justiça da guerra (jus ad bellum) devem ser diferenciadas daquelas que governam uma conduta justa e correta na guerra (jus in bello), como as encontramos hoje na Convenção de Genebra.

Quando retomou este tema em sua tentativa de estender uma teoria da justiça às relações internacionais em seu livro $O$ Direito dos Povos (The Law of Peoples, 1999), Rawls postulou uma Sociedade dos Povos com o intuito preciso de julgar os objetivos e limites da guerra justa, regulamentar a conduta recíproca e assegurar a coexistência pacífica dos povos (em contraposição a nações, de forma a viabilizar as reivindicações político-normativas de palestinos, bascos e curdos, por exemplo, que não são reconhecidos ainda como nações soberanas). $\mathrm{O}$ artigo seminal "The Law of Peoples" havia sido publicado em 1993, no periódico Critical Inquiry, seis anos antes de ser expandido e acrescido de outro ensaio, "A ideia de razão pública revisitada" (que havia sido publicado na University of Chicago Law Review, em 1997). O objetivo central do tratado é mostrar "como o conteúdo de um Direito dos Povos pode ser desenvolvido a partir de uma ideia liberal da justiça semelhante, embora mais geral do que a ideia da justiça como equidade" ". Trata-se, portanto, de uma alternativa viável para o realismo internacional que prevalecia nos centros de estudos internacionais e o cosmopolitismo ainda defendido por neokantianos, pacifistas e simpatizantes de alguma forma de utopia social.

8 RAWLS, J. The law of peoples, p. 3. 
Segundo Rawls, os povos são atores na Sociedade dos Povos assim como os cidadãos são os atores na sociedade nacional, com características institucionais, culturais e morais que os distinguem de Estados e nações, ao mesmo tempo em que determinam suas afinidades comuns e uma identidade coletiva como grupos sociais de indivíduos. É estabelecida, destarte, uma importante distinção entre direitos humanos básicos - estendidos a todos os povos - e os direitos de cada cidadão de uma democracia constitucional liberal. Rawls considera cinco tipos diferentes de sociedades nacionais, a saber: os povos liberais razoáveis (aqueles que aderem, numa maior ou menor proporção, aos princípios do Estado democrático de direito); os povos decentes (povos nãoliberais que não negam os direitos humanos, mas os reconhecem e os protegem); Estados fora da lei (regimes que se recusam a aquiescer a um Direito dos Povos razoável, recorrendo à guerra e ao terrorismo para promover seus interesses não-razoáveis); sociedades sob o ônus de condições desfavoráveis; os absolutismos benevolentes (povos que honram os direitos humanos mas negam aos seus membros um papel significativo nas decisões políticas). Rawls propõe, então, oito princípios de direito internacional: (1) os povos são livres e independentes, e sua liberdade e independência devem ser respeitadas mutuamente; (2) os povos devem observar tratados e compromissos; (3) os povos são iguais e são partes em acordos que obrigam; (4) os povos sujeitam-se ao dever de não-intervenção; (5) os povos têm o direito de autodefesa, único motivo legítimo para a guerra justa; (6) os povos devem honrar o direitos humanos; (7) os povos devem observar certas restrições especificadas na conduta da guerra; (8) os povos têm o dever de assistir a outros povos vivendo sob condições desfavoráveis 9 .

Segundo Rawls, o que é primordialmente importante para o Direito dos Povos é que a justiça seja assegurada pela estabilidade de sociedades liberais e decentes, mais ou menos como experienciamos hoje numa conjuntura relativamente estável de paz mundial entre a maior parte dos países-membros da Organização das Nações Unidas, com a exceção dos povos, grupos ou Estados "fora da lei”, na medida em que fomentam a guerra e o terrorismo. Uma intervenção militar com fins humanitários ou autodefesa seria, portanto, uma resposta legítima a tais abusos, e poderia ser caracterizada como uma instância de "guerra justa".

9 OLIVEIRA, N. Tout autre est tout autre: direitos humanos e perspectivismo semânticotranscendental. p. 98-108. 


\section{O pluralismo religioso de Geffré e o enigma da alteridade irredutível}

Professor de teologia por muitos anos no Saulchoir e no Instituto Católico de Paris, ex-diretor da Escola Bíblica de Jerusalém, Claude Geffré produziu uma vasta literatura na linha da teologia como hermenêutica em sua infindável busca de respostas razoáveis ao desafio imprescindível do pluralismo religioso contemporâneo através de uma abordagem hermenêutica da teologia. Segundo Geffré, uma teologia com orientação hermenêutica não designa apenas mais uma corrente teológica, mas "o próprio destino da razão teológica no contexto do pensável contemporâneo"10, pois diz respeito a uma nova postura diante do pluralismo religioso hodierno, o qual representa um novo paradigma teológico.

Há um enigma presente na alteridade plural das concepções religiosas, cuja manifestação expressa a riqueza espiritual da vivência humana do divino ${ }^{11}$. O sentido da verdade não pode ser completamente esgotado por nenhuma religião especificamente, porém, é em cada tradição religiosa, respeitada em sua alteridade irredutível, que se manifesta a verdade em sua contingência cultural e histórica. A própria teologia católica tem buscado superar uma postura eclesiocêntrica para abraçar um sentido mais ecumênico e reinocêntrico da revelação de Deus na história. Há uma nova sensibilidade em curso na elaboração teológica, menos exclusivista e mais inclusivista. Segundo Geffré, as religiões constituem mediações derivadas da vontade salvífica universal de Deus, sendo que cabe apenas a Jesus Cristo a mediação essencial, numa concepção cristológica e soteriológica sensível ao que Hans Küng denominou de Weltethos, uma ética global, de forma que os valores crísticos possam ser percebidos nas mais diversas religiões. O mistério de Cristo superabunda na história humana. A Igreja não é mediação exclusiva da salvação, mas um instrumento que se insere dentro da dinâmica da Economia da Salvação revelada na história humana. Deus pode agir além das mediações eclesiais. Além disso, todas as religiões

\footnotetext{
${ }^{10}$ GEFFRÉ, C. Crer e interpretar, p. 23.

11 "As religiões, cada uma delas, são totalidades complexas de resposta ao divino." (QUEIRUGA, A.T. O diálogo das religiões, p. 16). Na teologia contemporânea há a tendência em considerar a veracidade da pluralidade religiosa, pois estamos "diante de uma disseminação legítima das religiões: elas são caminhos autênticos na busca do divino." (DUQUOC, C. A teologia no exílio, p. 29).
} 
comportam ambiguidades, pois são objetivações relativas de uma realidade absolutamente maior, inabarcável e imanipulável.

Para Geffré, a própria humanidade de Jesus é marcada pela limitação, apesar de aberta às riquezas do Verbo. Jesus é ícone e não ídolo de Deus. A economia do Verbo encarnado é na realidade a manifestação de uma economia mais ampla ${ }^{12}$, embora seja a forma mais plena de expressão do mistério divino. O mistério da Encarnação revela a dinâmica quenótica do cristianismo e da teologia católica, cuja intrínseca dinâmica dialogal convida a reconhecer o outro e o diferente como irredutíveis à egolatria subjetiva do uno totalizante. É nas entranhas da lógica inclusiva que se deve buscar a dinâmica dialogal da revelação de Deus à humanidade. Não se deve confundir o reconhecimento de uma universalidade crística presente na pluralidade das manifestações religiosas com a defesa de uma cristandade enquanto religião histórica.

É preciso recolocar as bases da missão da teologia na perspectiva empática e dialogal de uma hermenêutica reinocêntrica da revelação de Deus, sem reduzir o outro à lógica particular de determinada tradição específica, mas intencionando uma autêntica metanoia, cujo resultado é a transformação recíproca pela busca comum da verdade. O pluralismo religioso emerge, portanto, como um novo paradigma teológico que nos convida a reinterpretar algumas das verdades fundamentais do cristianismo a partir da experiência histórica contemporânea, que concilia ao mesmo tempo secularização, ateísmo, indiferença religiosa, retorno ao religioso e concepções religiosas diversas que divergem da Bíblia. O diálogo ecumênico quebrou a postura católica hegemônica ${ }^{13}$. "O Vaticano II significou o fim de um certo absolutismo católico [...] que coincidia com um eclesiocentrismo"14. Pela primeira vez o Magistério da Igreja emite um julgamento positivo a respeito das outras

12 "O fundamento teológico do pluralismo religioso, que legitima o novo diálogo interreligioso recomendado pela Igreja, é a ideia de que a economia do Verbo encarnado é o sacramento de uma economia mais vasta que coincide com a história religiosa da humanidade. Quando se procura justificar, teologicamente, o diálogo inter-religioso, volta-se sempre para o mistério da Encarnação." (GEFFRÉ, C. De Babel a Pentecostes, p. 54).

13 "O ecumenismo é uma das grandes formas da experiência eclesial contemporânea. Sua opção é clara: regular pela negociação as questões que dividem as Igrejas. Esta opção é religiosa e política: ela é justificada pelas convicções evangélicas das confissões atualmente separadas e rompe com os enfrentamentos de caráter político que humilharam durante séculos a fé cristã, privando-a de seu horizonte fraterno." (DUQUOC, C. A teologia no exílio, p. 79).

${ }^{14}$ GEFFRÉ, C. Crer e interpretar, p. 132. 
confissões religiosas, assumindo uma postura de diálogo. A teologia é chamada a "reinterpretar a unicidade do cristianismo como religião de salvação entre as religiões do mundo" 15 , superando a ideia triunfalista do cristianismo sobre as outras religiões.

O fundamento teológico do pluralismo religioso e, portanto, do diálogo inter-religioso depende do fato de que a economia do Verbo encarnado é o sacramento de uma economia mais vasta, que coincide com a história religiosa da humanidade. Desde as origens, essa história não cessou de ser fecundada pelas sementes do Verbo e os dons do Espírito $^{16}$.

As diferenças religiosas são vistas, nessa perspectiva, como expressão das riquezas espirituais dispensadas por Deus aos povos. " $\mathrm{O}$ critério a partir do qual se deve interpretar o pluralismo das tradições religiosas é evidentemente a afirmação fundamental da vontade de salvação universal de Deus que se estende a todos os humanos"17. A salvação é destinada a todos os seres humanos, pois "Deus, nosso Salvador, quer que todos os homens sejam salvos e cheguem ao conhecimento da verdade" (ITm 2,3-4). Pentecostes é uma legitimação da pluralidade pela manifestação multiforme das expressões inesgotáveis na experiência de Deus. A multiplicidade de formas religiosas não contradiz a unidade do desígnio de Deus que pretende estabelecer aliança com o ser humano para salvá-lo. A possibilidade de salvação excede a mediação eclesiástica.

O Concílio Vaticano II, na Nostra Aetate n. 2, preferiu olhar positivamente para a tradição histórica das religiões, dizendo que suas tradições contêm prefigurações da religião cristã. É o caso de entender a singularidade da mediação de Cristo não de modo relativo, mas menos totalitário. É preciso respeitar a identidade do outro. "Temos dificuldade em assumir convicções que nos são cultural e religiosamente estranhas. É preciso tentar superar os próprios preconceitos históricos não criticados" 18 . Através de uma imaginação analógica, que percebe as semelhanças nas diferenças, mantendo as diferenças, é preciso escapar do equívoco sem cair em um unívoco. Mas é preciso ser fiel à própria

\footnotetext{
${ }^{15}$ GEFFRÉ, C. Crer e interpretar, p. 134.

${ }^{16}$ Idem. De Babel a Pentecostes, p. 8.

${ }^{17}$ Idem. Crer e interpretar, p. 136.

${ }^{18}$ Ibidem, p. 144.
} 
identidade, pois nem sempre são conciliáveis as diferentes verdades religiosas, há divergências fundamentais muitas vezes. É preciso manter a própria identidade para que se possa travar um diálogo sincero e frutuoso na integridade da interlocução, não sendo aconselhável proceder a uma suspensão provisória da própria fé como condição da abertura ao outro.

O cristianismo é uma realidade relativa, pois a verdade que testemunha não é nem exclusiva de toda outra verdade, nem mesmo absolutamente inclusiva, mas é relativa ao que há de verdadeiro nas outras expressões religiosas. "A superabundância do mistério de Cristo não encontrou sua tradução adequada no cristianismo histórico que conhecemos, e assim outras tradições religiosas podem misteriosamente encarnar certos valores crísticos"19. A fé cristã não pode prescindir de suas limitações enquanto fenômeno humano e histórico. Por isso, as outras religiões podem ajudar o cristianismo a explicitar melhor algumas das virtualidades do mistério cristão, pois segundo John Hick, todas as religiões, inclusive o cristianismo, giram em torno do mistério de Deus ${ }^{20}$; e segundo Raymond Panikkar, "as religiões giram em torno de Cristo"21, concebendo assim, um Cristo cósmico preexistente ${ }^{22}$.

Atualmente a humanidade vive uma era de mundialização, de globalização, de estreitamento das distâncias, graças às novas possibilidades de comunicação a nível planetário entre as pessoas. Surge a possibilidade de um ecumenismo planetário que promova na humanidade a consciência de constituir uma única família habitando em uma casa comum. Apesar dos contratestemunhos da história, "devemos questionar a ideia tipicamente moderna segundo a qual haveria uma contradição fatal entre a busca do absoluto e humano verdadeiro"23. Toda autêntica experiência religiosa coincide com certo descentramento de si e com a busca de um humanismo integral pela atitude da alteridade. Cabe à teologia, a partir da consciência de que "Deus não está preso às mediações eclesiais" ${ }^{24}$, reinterpretar o seu estatuto epistemológico, percebendo nas religiões possibilidades existenciais que favorecem a abertura ao mistério da salvação.

\footnotetext{
${ }^{19}$ GEFFRÉ, C. Crer e interpretar, p. 160.

${ }^{20}$ HICK, J. God has many Names.

${ }^{21}$ GEFFRÉ, C. Crer e interpretar, p. 163.

22 PANIKKAR, R. The unknown Christ of hinduism.

${ }^{23}$ GEFFRÉ, C. Crer e interpretar, p. 151.

${ }^{24}$ Ibidem, p. 159.
} 
A esta altura da reflexão podemos nos perguntar se a missão da Igreja ainda tem sentido. Podemos afirmar que a superação de um eclesiocentrismo fez a Igreja entender que "não é a Igreja que define a missão, mas é a missão que define a fisionomia da Igreja, a fim de que ela seja o sinal escatológico do Reino de Deus" ${ }^{25}$. A vocação histórica da Igreja não consiste na incorporação quantitativa de membros ao seu corpo, mas no testemunho que presta ao mundo do Reino de Deus cuja vinda é iminente. A missão nada perdeu de sua urgência mesmo que não vise primeiramente converter o outro "como se a mudança de religião fosse condição sine qua non de sua salvação"26. O testemunho prestado ao amor de Deus e aos valores do Reino, a conversão recíproca entendida como metanoia, são o fundamento da missão da Igreja.

O que dá finalidade a toda a atividade missionária da Igreja é proclamar em palavras e em atos que o Reino de Deus veio realmente em Jesus Cristo. O diálogo inter-religioso é um ato de esperança e de comunhão entre as pessoas. Não é apenas uma exigência do respeito da liberdade do outro, um ato de tolerância: é uma exigência do respeito devido aos caminhos misteriosos de Deus no coração da pessoa humana ${ }^{27}$.

Em seu livro Vers une théologie du pluralisme religieux ${ }^{28}$, Jacques Dupuis opta por uma misteriosa complementaridade entre as tradições religiosas. Ele segue a linha de pensamento de Teilhard de Chardin o qual tem uma perspectiva de convergência universal no fim dos tempos de todos no Cristo Ômega ${ }^{29}$. Para Claude Geffré, complementaridade "não respeita devidamente a alteridade irredutível de cada tradição religiosa. [...] É preferível suportar com paciência e tolerar intelectualmente o enigma do pluralismo religioso" 30 . É preciso respeitar os caminhos misteriosos de Deus no coração da humanidade com humildade e

\footnotetext{
${ }^{25}$ GEFFRÉ, C. Crer e interpretar, p. 172.

${ }^{26}$ Ibidem, p. 174.

${ }^{27}$ Ibidem, p. 176.

${ }^{28}$ DUPUIS, J. Vers une théologie du pluralisme religieux.

${ }^{29} \mathrm{Na}$ Obra de Teilhard, o ponto Ômega pode significar: "1 - O ponto de convergência natural da história humana e da evolução cósmica. [...] 2 - O ponto Ômega imanente ao mundo pode ganhar expressão pessoal no Deus transcendente da fé. [...] 3 - Outras vezes designa o Cristo ressuscitado. O Cristo na parusia incorpora o mundo e a humanidade ao Corpo Místico, no acabamento do Cristo Total." (ZILLES, U. Pierre Teilhard de Chardin, p. 120).

${ }^{30}$ GEFFRÉ, C. Crer e interpretar, p. 178.
} 
"acautelar-se de uma visão global ou de uma explicação totalitária"31, procurando ler na história os sinais de sabedoria e de esperança que nos permitam interpretar melhor o sentido de nossa vida.

Deve-se interpretar a diversidade dos fenômenos religiosos à luz da afirmação fundamental do Novo Testamento relativa à vontade de Deus de salvação universal, vontade que se estende a todos os homens desde as origens: "Deus quer que todos os homens sejam salvos e cheguem ao conhecimento da verdade" $(1 T m 2,4)$. E no seu discurso aos pagãos, Pedro declara: "Verifico que Deus não faz acepção de pessoas, mas que, em qualquer ação, quem o teme e pratica a justiça lhe é agradável" (At 10,34-35). Assim, o pluralismo religioso pode ser considerado como um desígnio misterioso de Deus cuja significação última nos escapa ${ }^{32}$.

Nesse sentido, Claude Geffré faz três observações fundamentais no tocante à teologia da revelação lida e interpretada a partir do paradigma pluralista, em uma perspectiva hermenêutica:

1. Hoje temos consciência mais viva de que a Palavra de Deus não se identifica nem com a letra da Escritura, nem com a letra dos enunciados dogmáticos. Dogma e Escritura são testemunhos parciais da plenitude do Evangelho, que é de ordem escatológica. 2. A revelação não é a comunicação, a partir do alto, de um saber fixado vez por todas. Ela designa, ao mesmo tempo, a ação de Deus na história e a experiência de fé do povo de Deus, que se traduz em expressão interpretativa dessa ação. Em outras palavras, o que chamamos Escritura já é interpretação. E a resposta da fé pertence ao próprio conteúdo da revelação. 3 . A revelação atinge sua plenitude, seu sentido e sua atualidade somente na fé que a acolhe. Por isso a revelação, enquanto Palavra de Deus numa palavra humana ou vestígio de Deus na história, não se sujeita a método científico, histórico-crítico. A fé, em seu aspecto cognitivo, é sempre conhecimento interpretativo marcado pelas condições históricas de uma época. E a teologia, enquanto discurso interpretativo, não é somente a expressão diferente de um conteúdo da fé sempre idêntico, que escaparia à historicidade. Ela é também a interpretação atualizante do próprio conteúdo da fé. ${ }^{33}$

${ }^{31}$ DUQUOC, C. A teologia no exílio, p. 100.

32 GEFFRÉ, C. De Babel a Pentecostes, p. 52.

${ }^{33}$ Idem. Como fazer teologia hoje, p. 18. 


\section{Hermenêutica teológica e política em Rawls e Geffré}

Diante da atual polifonia religiosa entoada pela multiplicidade de religiões do mundo, com suas consonâncias e dissonâncias, o cristianismo é chamado a expressar e a redefinir a sua identidade singular. Para Geffré, o sagrado só pode ser concebido como um fenômeno multifacetado. O modelo hermenêutico tem como ponto de partida o texto, compreendendo-o a partir de uma dada tradição contextual a qual fornece os esquemas interpretativos a partir dos quais a realidade referida é compreendida e os conceitos são elaborados ${ }^{34}$. Não há pensamento fora da linguagem e da cultura circunstancial ${ }^{35}$. Em suas próprias palavras:

Não há conhecimento do passado sem precompreensão e sem interpretação viva de si mesmo. Estamos sempre inscritos numa certa tradição de linguagem que nos precede. E é pelo fato de pertencermos à mesma tradição que aquela que suscitou o texto, que temos alguma chance de compreendê-lo. [...] O perigo permanente de uma atitude hermenêutica é adaptar a mensagem cristã aos imperativos da cultura histórica dominante e aos interesses da comunidade. A tarefa mais urgente é não apenas fazer um bom diagnóstico de nossa situação presente, mas saber reconstruir as estruturas constantes da experiência cristã de uma salvação em Jesus Cristo. Não há tradição viva se não houver atualização da experiência cristã fundamental. [...] Não há compreensão da fé sem reinterpretação criadora. [...] Trata-se de proceder de tal maneira que a revelação seja um evento sempre contemporâneo ${ }^{36}$.

\footnotetext{
34 "Poderíamos descrever a teologia como fenômeno de escritura. De fato, como no caso de toda escritura, trata-se sempre de 'reescritura'. Em cada época de sua história, a teologia se atribuiu a tarefa de tornar mais inteligível e mais falante a linguagem já construída da revelação. Essa linguagem é privilegiada e normativa para toda a fé da Igreja. Mas não podemos contentar-nos com repeti-la passivamente. Ela deve ser, sem cessar, reatualizada de maneira viva, em função de situação histórica nova e em diálogo com os recursos inéditos de dada cultura. A teologia é, pois, 'reescritura' a partir de escrituras anteriores, não somente da Escritura-fonte do dois testamentos, mas também das novas escrituras suscitadas por ela ao longo da vida da Igreja." (GEFFRÉ, C. Como fazer teologia hoje, p. 64-65).

35 "Sabe-se que, tradicionalmente, o Cristianismo, como outras religiões, tende a proclamar a posse da verdade. No entanto, por definição, a própria verdade cristã é maior e transcendente, portanto, irredutível a qualquer apreensão histórica. A sua adesão só é possível na liberdade e sob os condicionamentos da existência humana. Manifesta-se na responsabilidade razoável de expressão e comunicação dessa convicção, recebida em forma de palavra ou tradição, oral ou escrita. Introduz-se, então, entre a verdade e o seu pesquisador, entre o em-si e o em-mim, a distância de um caminho, o em-si que se faz outro para mim." (HAMMES, E.J. Hermenêutica e teologia, p. 57). A consciência desse distanciamento da verdade nos leva à humildade da postura hermenêutica em teologia.

${ }^{36}$ GEFFRÉ, C. Crer e interpretar, p. 24-25.
} 
Em teologia, os testemunhos buscam traduzir o acontecimento fundador, superando a tentação fundamentalista que favorece a busca de uma palavra pura e original. A releitura da tradição em contexto sincrônico e diacrônico ${ }^{37}$, na sua atualidade e conformação, busca discernir a experiência histórica que subjaz às formulações dogmáticas. Para compreender o alcance de um enunciado dogmático é preciso forjar a situação hermenêutica correta que é determinada pelo jogo da pergunta e da resposta. Fazer uma boa pergunta é formular a questão à qual o texto responde. Uma definição dogmática só pode ser compreendida em relação com a questão histórica que a provocou. Há nisto uma verdade bem profunda. Todo texto é uma resposta a uma pergunta e não podemos compreender a resposta contida no texto enquanto não tivermos compreendido a pergunta à qual o texto responde ${ }^{38}$.

$O$ procedimento interpretativo pode ser aplicado não apenas aos textos da revelação, como também aos textos da tradição dogmática. Tal atividade requer fidelidade ao passado e criatividade na aplicabilidade no presente. $\mathrm{O}$ que é transmitido, o acontecimento Jesus Cristo, é uma realidade sempre atual. Por isso, a tradição cristã precisa ser compreendida na sua dinâmica de inserção no coração da história. A missão da teologia hermenêutica é atualizar para o hoje da história humana a mensagem perene da revelação.

Trata-se sempre do diálogo de um leitor com um texto, o texto que me fala e que me faz perguntas. Mas eu também não sou puramente passivo: faço perguntas ao texto. E tenho chances de colocar boas questões, se elas estão no ponto de encontro do horizonte do texto com o meu próprio horizonte de compreensão. É esta dialética do texto e do leitor que fornece progressivamente o horizonte justo que vai permitir-me atingir a verdade cujo portador é o texto. [...] Não há tradição viva se não houver atualização da experiência cristã fundamental da revelação, mesmo que seja segundo interpretações diferentes ${ }^{39}$.

\footnotetext{
37 "Podemos (1) estudar o texto em sua condição atual, ou (2) procurar explicar como se formou a redação que chegou até nós. No primeiro caso, dá-se uma leitura chamada sincrônica (sincronia = contemporaneidade; do grego $\sigma u ́ v=$ junto, $\operatorname{com} ; \chi \rho o ́ v o \varsigma=$ tempo); no segundo, a leitura é do tipo diacrônico (diacronia = evolução; do grego $\delta$ ió = através de; $\chi \rho o ́ v o \varsigma=$ tempo)." (SILVA, C.M.D da. Metodologia da exegese bíblica, p. 80-81).

${ }^{38}$ GEFFRÉ, C. Crer e interpretar, p. 69-70.

${ }^{39}$ Ibidem, p. 42.
} 
As confissões de fé emergem da tradição, cujas definições não podem ser concebidas apenas como atos de jurisprudência, mas sim como a tradução de atos de interpretação que buscam responder às situações existenciais de crise, onde o elemento da fé é questionado ${ }^{40}$. A mudança das situações contextuais provoca uma adequação do sentido original à realidade em questão. A dinâmica da recepção provoca uma abertura de sentido aos enunciados da fé revelada e elaborada dogmaticamente. A disposição em retomar de modo criativo o sentido da fé em vista das novas experiências históricas, traz uma vitalidade aos enunciados da fé:

A hermenêutica teológica não diz respeito apenas à leitura de nossas Escrituras fundadoras, mas à releitura da tradição, em particular das fórmulas dogmáticas. De fato, seria paradoxal que tivéssemos uma liberdade bem menor de interpretação a propósito dos enunciados dogmáticos do que no caso dos textos da Escritura ${ }^{41}$.

Como foi assinalado acima, o que chama atenção na leitura que Rawls faz do problema da guerra justa é que, embora se mantenha inalterada desde suas primeiras formulações nos anos 1960, culminando com a Teoria da Justiça em 1971, até as suas reformulações tardias do liberalismo político nos anos 1980, culminando com o Direito dos Povos em 1999, o seu modo de apresentação favorece uma maior abertura dinâmica para o diálogo, a tolerância e o acolhimento do Outro, do estrangeiro e do imigrante. Em vez de partir de um experimento mental (thought experiment, Denk-Experiment), com eus noumênicos (noumenal selves) ou pessoas livres e iguais com sentido de justiça e concepção do bem, Rawls mantém o procedimentalismo do equilíbrio reflexivo em sentido inverso, partindo da teoria não-ideal (de pessoas concretas numa cultura política, onde se dão os conflitos e embates entre

\footnotetext{
40 “A verdadeira tradição não é a transmissão mecânica de um conteúdo doutrinal no sentido de uma invariante quimicamente pura. Ela é feita de retomadas criativas da mensagem cristã. Podemos considerar o Novo Testamento como o ato de interpretação da primeira comunidade cristã e a distância que nos separa dela, longe de ser um obstáculo, é a condição de um novo ato de interpretação hoje. Deste modo, o cristianismo é tradição porque ele vive de uma origem primeira que é dada, que nos precede, mas ao mesmo tempo é necessariamente inovação, porque esta origem só pode ser redita historicamente e segundo uma interpretação criativa. E atualizar a tradição é propor novas interpretações da Escritura, dos símbolos da fé, das fórmulas dogmáticas." (GEFFRÉ, C. Crer e interpretar, p. 67-68).

${ }^{41}$ GEFFRÉ, C. Crer e interpretar, p. 25.
} 
doutrinas abrangentes) em direção à normatividade idealizada em textos constitucionais, normas e convenções internacionais, servindo-se de uma epistemologia social de coerência, em que um conjunto de crenças é concatenado e consolidado através de um processo de ajuste mútuo, recursivo, retroalimentado, calibrado e deliberativo entre juízos morais particulares e os princípios gerais e as construções teóricas adotados pelas partes envolvidas.

A hermenêutica política emerge nesse espaço de razão pública onde se dá o consenso sobreposto: como doutrinas religiosas e concepções abrangentes do bem conflitantes e incompatíveis podem se mostrar razoáveis, na esfera pública, de forma a permitir sua coexistência pacífica? O liberalismo político busca acomodar tal pluralidade de doutrinas abrangentes razoáveis através do consenso sobreposto, por exemplo, quando todas as partes subscrevem a concepções minimalistas de direitos humanos. Depois de sua morte, Rawls ainda suscitou vários debates em torno do problema da secularização e da religião em sociedades democráticas contemporâneas, sobretudo após publicações póstumas de alguns de seus escritos sobre a religião. $\mathrm{O}$ fato de reconciliar sua visão político-liberal da democracia com uma concepção heterodoxa de igualitarismo social permite não apenas uma reformulação do que seria um socialismo liberal ou de um liberalismo social (como o encontramos em Norberto Bobbio), mas também de uma concepção liberal de teologia política.

O jovem Rawls retomou o termo "inquérito" (inquiry), que era utilizado pelos interlocutores deístas e iluministas quando questionavam a teodiceia e tentativas de justificação racional do problema do mal, em seu trabalho de conclusão de curso (Senior thesis), Breve Inquérito sobre o significado do pecado e da fé: Uma interpretação baseada no conceito de comunidade (A Brief Inquiry into the Meaning of Sin and Faith: An Interpretation Based on the Concept of Community), defendido na Princeton University em dezembro de 1942. O fato de Rawls ter confessado mais tarde que teria abandonado suas crenças religiosas depois de ter conhecido os horrores da Segunda Guerra e do Holocausto é bastante instrutivo. Em seu escrito autobiográfico "On My Religion" (1997), tal mudança no pensamento de Rawls foi marcada pelo estudo da história da Inquisição, logo nos primeiros anos após a guerra, tendo servido como marine (fuzileiro naval) no Pacífico, pela rejeição da ortodoxia (nas palavras do jovem Rawls, "o poder político para estabelecer a sua hegemonia e para oprimir outras religiões"), 
pela Ética Teológica e pela Teologia Política. Rawls entendeu que o problema teológico da justificação seria correlato ao da justiça política, em seu intento programático de "interpretar a história como a expressão da vontade de Deus, a vontade de Deus devendo estar de acordo com as ideias mais básicas de justiça como nós as conhecemos". Rawls observara com bastante propriedade que enquanto a religião grega e romana era uma religião cívica, servindo para incutir lealdade para com a polis ou o Imperador, especialmente em tempos de guerra e de crise, permitindo um certo tipo de pluralismo religioso, a história da Igreja Cristã desvela os profundos laços históricos com o Estado e seu uso do poder político para estabelecer sua hegemonia e para suprimir ou oprimir outras religiões. Rawls observa que seria contra esse pano-defundo de religiões expansionistas como o Cristianismo e o Islamismo que se promoveria o interesse comum em uma guerra justa enquanto defesa nacional ${ }^{42}$.

Segundo Rawls, o Cristianismo Medieval tinha cinco características que a religião cívica ignorava: tendia a uma religião autoritária, cuja autoridade era institucional, centralizada e quase absoluta, embora a autoridade suprema do papa tivesse sido algumas vezes contestada (por exemplo, no período conciliar dos séculos XIV e XV), era uma religião salvacionista, onde um único caminho para a vida eterna e para a salvação exigia uma crença verdadeira a ser ensinada pela Igreja. Neste sentido, o Cristianismo se consolidaria como uma religião doutrinária com um credo que devia ser professado. Era uma religião de sacerdotes com a única autoridade para dispensar meios de graça, significa normalmente essencial para a salvação. Finalmente, era uma religião expansionista de conversão que não conhecia limites territoriais para sua curta autoridade do mundo como um todo. A Reforma teve enormes consequências. Como autoridade salvacionista e religião expansionista que dividiu o cristianismo medieval, esta inevitavelmente significa a aparência dentro da mesma sociedade de uma religião autoritária e salvacionista rival, diferente em alguns aspectos da religião original a partir da qual se separou, mas que por um determinado período de tempo teve muitas das mesmas características.

Considerar a teologia como hermenêutica é repor em causa a distinção entre o dado e o construído, estudada na teologia tradicional, e ultrapassar a oposição entre uma teologia dita positiva e uma teologia

42 RAWLS, J. A theory of justice, $\S \S 25,39$. 
dita especulativa, que há mais de três séculos compromete a unidade do saber teológico. De fato, essa distinção consagrava o divórcio entre a razão e a história no trabalho teológico e o triunfo de uma escolástica separada de suas fontes bíblicas. O positivismo histórico e o racionalismo teológico têm a mesma origem, a saber, o desconhecimento de verdadeira compreensão hermenêutica do passado. Nós já o sugerimos: esse desconhecimento é herança da distinção kantiana entre o conhecimento dos fatos e a procura do sentido. A teologia dita positiva se limitava a registrar documentos do passado. Isso feito, a teologia especulativa podia entregar-se ao seu trabalho de construção teórica, como se pudéssemos contentar-nos com distinção ingênua entre um dado cujo sentido pudéssemos ler, pondo entre parênteses nossa compreensão de hoje, e uma construção que tivesse apenas relação distante com esse dado. Sabemos que não podemos fazer o inventário das fontes da fé, sem nos darmos a todo um trabalho de interpretação ${ }^{43}$.

Em sua obra-prima de 1971, a doutrina da guerra justa aparece ao lado de temas tais como a teoria da punição, a justificação das várias maneiras de se opor a regimes injustos, a desobediência civil e a objeção de consciência ${ }^{44}$. $O$ contexto semântico-conceitual ainda seria o da concepção ideal de justiça, quando perguntamos se, e em que circunstâncias, arranjos injustos devem ser tolerados, ou seja, como a concepção ideal de justiça se aplica aos casos em que, em vez de ter que fazer ajustes para limitações naturais, somos confrontados com a injustiça ${ }^{45}$. Assim, Rawls se coloca a pergunta: "Será que o pacifista possui uma imunidade de serviço militar em uma guerra justa, assumindo que existem essas guerras? Ou é o estado autorizado a impor certas dificuldades resultantes da não-conformidade?"46

O princípio básico do Direito dos Povos é um princípio de igualdade, a saber, que povos independentes organizados como Estados têm certos direitos fundamentais iguais. Este princípio é análogo ao da igualdade de direitos dos cidadãos em um regime constitucional. Uma das consequências dessa igualdade dos povos e das nações é o princípio da autodeterminação, qual seja, o direito de um povo a que possa resolver os seus próprios assuntos sem a intervenção de potências

\footnotetext{
${ }^{43}$ GEFFRÉ, C. Como fazer teologia hoje, p. 24-25.

${ }^{44}$ RAWLS, J. A theory of justice, p. 8.

${ }^{45}$ Ibidem, § 5, p. 309.

${ }^{46}$ Ibidem, § 56, p. 325.
} 
estrangeiras. Outra consequência é o direito de autodefesa contra-ataques externos, incluindo o direito de formar alianças defensivas para proteger este direito. Um outro princípio é que os tratados, pactos e acordos devem ser mantidos, desde que sejam coerentes com os outros princípios que regem as relações dos Estados. Quando uma nação tem uma justa causa na guerra ou, na frase tradicional, seu jus ad bellum, pode ocorrer também que os princípios que regulam os meios que pode usar para fazer a guerra, seu jus in bello, sejam ou não aceitáveis segundo argumentos razoáveis ${ }^{47}$. Segundo Rawls, outro aspecto que devemos contrastar com o mundo clássico é que durante as guerras de religião as pessoas não estavam em dúvida sobre a natureza do bem maior, ou sobre a base da obrigação moral na lei divina. Na concepção clássica da guerra justa, os fiéis achavam que sabiam com a certeza da fé, na medida em que a sua teologia moral deu-lhes orientação completa para resolver os seus conflitos com outros credos ou outras interpretações da fé cristã. Nesse sentido, podemos nos questionar: Como é a sociedade ainda possível entre aqueles de diferentes credos? O que pode ser concebível sobre a base da tolerância religiosa? Assim, a origem histórica do liberalismo político (e do liberalismo mais geral) encontra-se na Reforma, suas contradições e consequências, com as longas controvérsias sobre a tolerância religiosa nos séculos XVI e XVII.

Embora a formulação original de uma teoria da justiça como equidade tenha sido revista e reformulada pelo próprio Rawls ao longo de seus escritos tardios, o intento programático de justificar a coexistência pacífica de grupos sociais conflitantes numa mesma sociedade civil é preservado e radicalizado através de vários argumentos que retomam a questão diretriz da tolerância política: "Como tolerar o intolerante? Como reconciliar interesses incompatíveis através de uma concepção pública de bem comum?" ${ }^{48}$ Em seu Liberalismo Político, John Rawls observa de maneira um tanto instrutiva que Lutero e Calvino foram tão dogmáticos e intolerantes quanto a Igreja Católica Romana tinha sido antes deles ${ }^{49}$. Contudo, segundo Rawls, a Reforma do século XVI inaugurou de maneira definitiva o pluralismo religioso no mundo ocidental moderno. Se os gregos, assim como as religiões politeístas em geral, eram bem mais tolerantes do que os povos que adeririam a religiões monoteístas,

\footnotetext{
${ }^{47}$ RAWLS, J. A theory of justice, $\S 58$, p. 332.

48 Ibidem, $\S \S 34,35$.

${ }^{49}$ Idem. Political liberalism, p. 25.
} 
em particular ao cristianismo depois da conversão de Constantino, só foi com a Reforma que foi concretizado o problema do liberalismo político, a saber, "como é possível existir, ao longo do tempo, uma sociedade estável e justa de cidadãos livres e iguais, profundamente divididos por doutrinas religiosas, filosóficas e morais razoáveis". (How is it possible that there may exist over time a stable and just society of free and equal citizens profoundly divided by reasonable religious, philosophical, and moral doctrines?)

De acordo com Rawls, a liberdade dos antigos se diferencia da dos modernos não apenas pela emergência de um novo paradigma de subjetividade (o indivíduo político, seus direitos civis e suas liberdades básicas) mas ainda - e de maneira mais fundamental - pela introdução deste "choque entre religiões salvacionistas, doutrinárias e expansionistas" e pela internalização de tal conflito "latente e irreconciliável": "A novidade em relação a esse choque" (clash), escreve Rawls, "é que ele introduz nas concepções de bem das pessoas um elemento transcendental que não admite conciliação. Esse elemento conduz forçosamente ou a um conflito mortal, moderado apenas pela circunstância e pela exaustão, ou a liberdades iguais de consciência e de pensamento. Exceto por essas últimas, firmemente arraigadas e publicamente reconhecidas, nenhuma concepção política razoável de justiça é possível". É neste sentido, portanto, que Rawls pode asserir, em tom de constatação, que "a origem histórica do liberalismo político e do liberalismo em geral está na Reforma e em suas consequências, com as longas controvérsias sobre a tolerância religiosa nos séculos XVI e XVII". E Rawls ainda comenta, não sem ironia, que "como Hegel sabia muito bem, o pluralismo possibilitou a liberdade religiosa, algo que certamente não era a intenção de Lutero, nem de Calvino", fazendo alusão ao parágrafo 270 das Grundlinien der Philosophie des Rechts de $1821^{50}$. Decerto, toda a filosofia política da tolerância que seria desenvolvida de John Locke, no final do século XVII, até John Stuart Mill, em meados do século XIX, marcaria uma evolução notável na aplicação de conceitos fundamentais como justiça, liberdade e igualdade a esferas cada vez mais abrangentes do tecido social e das instituições sociais, econômicas e políticas. Basta lembrar que um autor como Hobbes, apesar de suas críticas veementes à Igreja e de ter sido aparentemente indiferente à religião, se opôs taxativamente à tole-

\footnotetext{
${ }^{50}$ RAWLS, J. The law of peoples, p. 32.
} 
rância religiosa e não tolerou os calvinistas e membros de outras seitas protestantes.

De resto, as guerras religiosas e as grandes insurreições, rebeliões e guerras civis nos séculos XVI e XVII pareciam solapar a estabilidade do Estado de direito. Os modelos jusnaturalistas procurariam, portanto, estabelecer de maneira definitiva uma justificação coerente do poder instituído - que, em última análise, mesmo sem recorrer ao direito divino dos reis era também representado na vida religiosa do povo e seus líderes espirituais. O problema de tolerar diferentes concepções do divino, sob a ameaça constante de grandes heresias, apostasias e cisões, inevitavelmente nos remeteria, numa situação extrema, ao problema de até que ponto pode-se tolerar o intolerante ${ }^{51}$. Rawls observa que antes da prática pacífica e bem-sucedida da tolerância em sociedades com instituições liberais, não havia como saber da existência da possibilidade de uma sociedade pluralista estável e razoavelmente harmoniosa. Por isso, a intolerância foi aceita durante tantas décadas, mesmo depois da Reforma, como uma condição da ordem e estabilidade sociais. Certamente a secularização - e este foi um processo que se desenvolveu paulatinamente a partir de concepções liberais em círculos teológicos - viria a coroar de vez a especificidade do liberalismo político, autodiferenciado do problema do bem supremo. Como Rawls observa, para os modernos, o bem se dava a conhecer em sua religião; com suas divisões profundas, o mesmo não se verificava em relação às condições essenciais de uma sociedade viável e justa. Assim as diferenciações das esferas do político, do social e do econômico seguem organicamente a separação pós-luterana entre a esfera eclesiástica e a esfera civil.

Segundo John Rawls, a característica mais fundamental e permanente de uma cultura política democrática, pública, é precisamente o que ele denomina o "fato do pluralismo razoável". De acordo com o Liberalismo Político, tal "cultura pública compreende as instituições políticas de um regime constitucional e as tradições públicas de sua interpretação (inclusive as do judiciário) [sem grifos no original]" 52 . Além de ser uma concepção moral especificamente política - na medida em que se aplica à "estrutura básica da sociedade", isto é, às instituições políticas, sociais e econômicas de uma democracia constitucional moderna - e de ser apresentada como uma "visão autossuficiente"

\footnotetext{
${ }^{51}$ RAWLS, J. A theory of justice, $\S 35$.

52 Idem. Political liberalism, p. 53.
} 
(freestanding view) - diferenciada, portanto, em sua especificidade política de doutrinas abrangentes (comprehensive doctrines) morais, religiosas e filosóficas -, a "justiça como equidade" parte de "uma certa tradição política", assumindo como sua ideia fundamental a da "sociedade como um sistema equitativo de cooperação ao longo do tempo, de uma geração até a seguinte". E Rawls acrescenta, "essa ideia organizadora central corre paralela a duas outras, fundamentais, que são suas companheiras inseparáveis: a de que os cidadãos (aqueles envolvidos na cooperação) são pessoas livres e iguais; e a de que uma sociedade bem-ordenada é efetivamente regulada por uma concepção política de justiça. Supomos também que essas ideias podem ser trabalhadas numa concepção política de justiça capaz de conquistar o apoio de um consenso sobreposto [overlapping consensus]" ${ }_{53}$.

Somente assim, podemos compreender por que o massacre de São Bartolomeu, em 1572 (Massacre de la Saint-Barthélemy, quando cerca de 10 mil huguenotes teriam sido assassinados por católicos fanáticos) e as guerras religiosas são tomadas pelo jovem Rawls e evocadas em seus escritos tardios como importantes marcos do desenvolvimento e evolução da democracia liberal na Europa e no mundo ocidental. Rawls observa ainda que "não deve ser esquecido o fato de que a concepção demoníaca de Hitler do mundo era, de certa forma perversa, religiosa. Isto é evidente a partir de sua derivação e de suas principais ideias e ódio. O seu antissemitismo redentor, como Saul Friedlander o chama, inclui elementos não apenas raciais... mas nasce do medo da degeneração racial e da crença religiosa na redenção." Rawls observa, destarte, uma vergonhosa linha de ódio religioso que buscava justificar de forma irracional a guerra, desde as guerras étnico-religiosas e o antissemitismo na Antiguidade e no Medievo até as suas versões modernas e o Holocausto ${ }^{54}$.

Como reação a um clima de relativismo generalizado, segundo Geffré, emergem as posturas fundamentalistas, as quais surgem como uma pedra de tropeço contra toda plausibilidade científica e histórica, provocando um suicídio intelectual. Os fundamentalistas não admitem a dinâmica hermenêutica e histórica da fé, caindo em um hermetismo doutrinal e anacrônico, que só concebe uma veracidade das Escrituras Sagradas se estas estiverem o mais perto possível da fonte, que seriam

\footnotetext{
${ }^{53}$ RAWLS, J. Political liberalism, $\S \S 3.3,5,6$, p. 57-58.

${ }^{54}$ Idem. The law of peoples, p. 20 ss.
} 
as palavras originais de Jesus. O pressuposto consiste na crença de que quanto mais primitivo é o testemunho, mais original ele seria.

A constituição do Novo Testamento como ato de revelação da primeira comunidade cristã prolongou-se por um período de uns trinta ou quarenta anos. O que resultou por escrito no final deste processo não é menos importante do que o que foi escrito no começo. Mas alguns exegetas recusam os dados mais comprovados porque, para eles, a oralidade é como que investida de um poder muito maior do que a escrita. Eles desejariam encontrar um escrito primitivo que fosse exatamente a estenografia da palavra viva de Deus. [...] É impossível termos acesso direto à palavra viva de Jesus. Sempre a encontramos por meio dos textos e é por isso que podemos interrogar-nos sobre um método exegético que quer centrar tudo no que se chama sentido literal. [...] É preciso aceitar a passagem por meio da linguagem, e quem diz linguagem diz ao mesmo tempo interpretação em relação a um evento e em relação ao testemunho oral. Alguns têm a obsessão da pureza originária ${ }^{55}$.

O paradigma pluralista permite uma humilde interpretação dos enunciados da fé de modo a procurar "dar as razões da própria esperança àqueles que as pedirem" (cf. $1 P d 3,15$ ). O desígnio misterioso de Deus nos insere nessa dinâmica dialética de revelação e escondimento, em que é preciso admitir que não se tem o controle total e absoluto da situação, nem que é possível tutelar conceitualmente as verdades divinas, mas que somos envolvidos por algo que foge à nossa plena compreensão, apesar de não ser contraditório à nossa racionalidade. Ser pluralista significa admitir que toda significação última nos escapa.

\section{Algumas aproximações teológico-políticas entre Rawls e Geffré}

Ora, as recentes incursões do Estado Islâmico e os frequentes ataques terroristas perpetrados por grupos fundamentalistas têm ajudado a propagar sentimentos religiosos e antirreligiosos por razões bastante simples de serem constatadas, mas que revelam a complexidade dos temas e problemas correlatos da teologia política. Ao contrário de uma versão de teologia política antimodernista ou antiesclarecimento,

${ }^{55}$ GEFFRÉ, C. Crer e interpretar, p. 92-93. 
como a de Carl Schmitt, Rawls se aproxima da abordagem políticoteológica liberal, como a de Geffré, seguindo Johann Baptist Metz ao defender o pluralismo razoável numa esfera pública pós-secular (como diria Habermas), onde o papel da religião assume publicamente seu diálogo com um conceito do político (das Politische) em constante redefinição democrática, desmistificado pela deliberação pública nas democracias modernas, resgatando concepções teológicas que foram secularizadas, tais como "soberania" e "autoridade", e voltaram a ser revisitadas na própria formação de opinião e vontade, inerentes a processos de aprendizagem da democracia, não apenas em suas respectivas transformações semânticas, mas sobretudo em suas pretensões normativas de validade.

Tanto Rawls quanto Geffré recorrem a modelos construtivistas mitigados, na medida em que a construção social que permite o diálogo e a deliberação pública podem ser tomados como exemplos defensáveis de um construcionismo social metodológico fraco que enfrenta os desafios do relativismo cultural e do pluralismo dos contextos semânticos intersubjetivos, sem abdicar de uma concepção de normatividade éticomoral, embora não absolutista, permitindo a identidade religiosa em meio a celebrações de diversidade e tolerância. A fim de reconstruir uma hermenêutica da guerra justa, podemos recapitular, em conclusão, que assim como a linguagem antropocêntrica e a historicidade eurocêntrica do jusnaturalismo moderno prepararam o terreno para implementar uma declaração universal dos Direitos Humanos logo após a Segunda Guerra Mundial e para reabilitar possíveis doutrinas da guerra justa no Século XX, princípios e suposições universalizáveis sobre a jus in bello postulam uma ideia de guerra justa unicamente travada por um povo em autodefesa ou para promover uma paz justa e duradoura entre povos, na medida em que os povos bem-ordenados (por exemplo, democracias) não declaram guerra uns aos outros, mas apenas contra Estados fora-da-lei ou cuja ambição expansionista visa ameaçar as instituições de regimes bem-ordenados ${ }^{56}$.

\section{Conclusão}

A hermenêutica teológica de Claude Geffré nos ajuda a reler o fenômeno da revelação em sua pluralidade irredutível, cuja riqueza

\footnotetext{
${ }^{56}$ RAWLS, J. The law of peoples, $\S \S 5,8$.
} 
não se esgota no cristianismo enquanto religião histórica, embora tenha nele, uma expressão privilegiada da manifestação do desígnio salvífico de Deus para a humanidade. Só é possível crer interpretando ${ }^{57}$, ou seja, atualizando para o hoje as experiências de ontem, abrindo um horizonte de esperança para o amanhã, como um descortinar do inefável para a imanência da história. A utopia social da escatologia cristã se encontra no mesmo horizonte de desafios normativos inerentes ao projeto rawlsiano de uma utopia realista. Não nos parece nada razoável, portanto, postular hoje uma pax americana que, assim como a pax romana há dois milênios, carece de fundamentos normativos pela própria imposição violenta de interesses econômicos e geopolíticos particulares. Rawls sempre foi, de resto, implacável nas suas críticas à política externa americana, desde o uso de bombas atômicas contra a população civil de Hiroshima e Nagasaki até a intervenção desastrosa contra regimes democráticos, como o de Allende, por interesses econômicos e ideológicos de "segurança nacional". Rawls também não hesitou em vincular o Holocausto nazista ao antissemitismo de uma certa interpretação cristã que permite a persistência da intolerância, reproduzida na Irlanda do Norte e no conflito palestino-israelense, e que continua sendo o maior desafio para a normatividade ético-política moderna, a saber, como diferentes doutrinas abrangentes (religiosas, morais, ideológicas), incompatíveis entre si, podem conviver pacificamente de forma a viabilizar a sociabilidade?

\section{Referências}

BOAVENTURA, Josuel dos Santos. O Deus único nas distintas formas de revelação. Teocomunicação, Porto Alegre, v. 36, n. 152, p. 383-421, jun. 2006.

DUPUIS, Jacques. Vers une théologie du pluralisme religieux. Paris: Du Cerf, 1997.

DUQUOC, Christian. A teologia no exílio: o desafio da sobrevivência da teologia na cultura contemporânea. Trad. Gentil Adelino Titton. Petrópolis: Vozes, 2006.

\footnotetext{
57 “A hermenêutica teológica, em seu cuidado por atualizar a Palavra de Deus para hoje, não se contenta com produzir novos comentários. À força de frequentar um texto que é a testemunha privilegiada da Palavra atuante de Deus, o teólogo tem a vocação exigente de exercer, isto é, de propor práticas significantes para a Igreja. Mas isso é pouco. A própria prática dos cristãos é lugar teológico que oferece dados ao teólogo em sua reinterpretação criativa da fé. Sob a ação do Espírito, que nunca lhe falta, a comunidade cristã toda tem competência para interpretar os 'sinais dos tempos' e para criar outras figuras históricas da plenitude insondável do mistério de Cristo.” (GEFFRE, C. Como fazer teologia hoje, p. 11).
} 
GEFFRÉ, Claude. De Babel à Pentecostes: ensaios de teologia inter-religiosa. Trad. Margarida Maria Cichelli Oliva. São Paulo: Paulus, 2013.

. Como fazer teologia hoje: hermenêutica teológica. Trad. Benôni Lemos. São Paulo: Paulinas, 1989.

. Crer e interpretar: a virada hermenêutica da teologia. Trad. Lúcia M. Endlich Orth. Petrópolis: Vozes, 2004.

GOMES, Tiago de Fraga. Hermenêutica teológica e teologia da revelação em Claude Geffré. In: SUSIN, Luiz Carlos; RODRIGUES, Jéferson Ferreira (Org.). Fazer teológico. Porto Alegre: Editora Fi, 2015. p. 49-71.

. A teologia hermenêutica de Claude Geffré e a sua relevância para a teologia da revelação. 2015. 140 f. Dissertação (Mestrado em Teologia) - Faculdade de Teologia, Pontifícia Universidade Católica do Rio Grande do Sul, Porto Alegre, 2015.

HAMMES, Érico João. Hermenêutica e teologia: interpretar é preciso. In: PICH, Roberto Hofmeister; ZILLES, Urbano (Org.). Filosofia, Ciência e Religião. Porto Alegre: Edições EST, 2009. p. 57-67.

HICK, John. God has many Names. Filadélfia: Westminster, 1980.

HOBSBAWM, Eric. A era dos extremos: o breve século XX: 1914-1991. Trad. Marcos Santarrita. São Paulo: Paz e Terra, 1995.

HUNTINGTON, Samuel. O choque de civilizações e a recomposição da ordem mundial. Rio de Janeiro: Objetiva, 1997.

NARDIN, Terry (Org.). The ethics of war and peace. Princeton, NJ: Princeton University Press, 1996.

OLIVEIRA, Nythamar de. Revisitando a crítica comunitarista ao liberalismo: Sandel, Rawls e teoria crítica. Síntese Revista de Filosofia, Belo Horizonte, v. 41, p. 393-413, 2014.

. Tout autre est tout autre: direitos humanos e perspectivismo semânticotranscendental. Veritas, Porto Alegre, v. 51, p. 98-108, 2006.

PANIKKAR, Raymond. The unknown Christ of hinduism. Mary-knoll: Orbis Books, 1981.

QUEIRUGA, Andrés Torres. O diálogo das religiões. São Paulo: Paulus, 1997.

RAWLS, John. The law of peoples. Cambridge, Mass.: Harvard University Press, 1999. . A theory of justice. Cambridge, Mass.: Harvard University Press, 1971. . Political liberalism. New York: Columbia University Press, 1996.

SILVA, Cássio Murilo Dias da. Metodologia da exegese bíblica. 3. ed. São Paulo: Paulinas, 2009.

SOLZHENITSYN, Alexander. Uma palavra de verdade. São Paulo: Hemus, 1972.

STEIN, Ernildo. Aproximações sobre Hermenêutica. Porto Alegre: Edipucrs, 1996. 
STRACHAN, Hew. European armies and the conduct of war. London: Routledge, 1998.

. Financing the war. Oxford: Oxford University Press, 2004.

. The first world war: to arms. Oxford: Oxford University Press, 2003.

WALZER, Michael. Just and unjust wars: a moral argument with historical illustrations. London: Allen Lane, 1978.

ZILLES, Urbano. Pierre Teilhard de Chardin: ciência e fé. Porto Alegre: Edipucrs, 2001.

Recebido em: 13/04/2016

Aprovado em: 29/07/2016 